\title{
DEVELOPING MUSHROOM GYMNASTIC INSTRUMENT PROTOTYPE FOR MEN'S ARTISTIC GYMNASTIC SPORT IN CENTRAL JAVA PROVINCE
}

\author{
Tommy Soenyoto \\ Graduate School, Universitas Negeri Jakarta \\ tommysoenyoto@gmail.com
}

\begin{abstract}
This study aims to develop mushroom gymnastic instrument for men's artistic gymnastic athletes of junior and senior levels. The instrument is aimed at improving movement skills on horse saddle. Aside from its use as an exercise instrument for beginner, junior and senior levels of men's artistic gymnastic athletes, this instrument can also be used for beginners' level competition. This study used qualitative approach in which the data are collected from the initial step to the trial. The main procedure involved five steps: (1) the analysis of product development; (2) the development of initial product; (3) the expert validation; (4) the trial; and (5) the product revision. This study found that the mushroom gymnastic instrument can be used for men's artistic gymnastic sport, particularly (1) for improving movement skill development on horse saddle for junior and senior athletes; (2) as an exercise instrument for beginner, junior and senior level of men's artistic gymnastic athletes; (3) as an instrument used in competition for men's artistic gymnastic for beginners' level.
\end{abstract}

Keywords: model development, prototype, mushroom gymnastics, men's artistic gymnastics sport.

Gymnastic is an effective sports to optimize children's growth and development. The movements of the sport are within the physical education program. The movements trigger all aspects of physical development, such as power and muscles endurance. Furthermore, gymnastic activates athletes' potential to develop basic movement skill as an important foundation to master technical skill in sports (Mahendra, 2001, p.?).

In sport achievement coaching, Subardijah (2000, p. 68) argues many factors must be considered in order achieve...well, such as clear development goal, systematic training program, proper material and training methods, and wellmaintained evaluation of the training program. There are also other consideration such as the athlete's physical and psychological characteristics, the coach's ability, the facilities and infrastructure, and the types of training (Soenyoto, 2004, p. 2).

Based on researcher's observation in 2007 to 2010, the facilities and infrastructure belonging to the Gymnastic Association Organization of Indonesia (Pengcab Persani) in Central Java is scarce. Similar conditions are found throughout the organization's branches throughout Central Java (Soenyoto, 2010). Despite this disadvantage, the 2010 competition report of Persani, Central Java stated that athletes who were facilitated with horse saddle and mushroom gymnastic instruments were able to gain gold medals in horse saddle competition. A closer investigation on the report archieves of Official Persani of Central Java on the O2SN competition in 2009 to 2011 found that athletes who won the gold medal in mushroom class competiton were the ones who came from the organization branches which utilized mushroom gymnastic instrument modified to follow the size 
prescribed in the regulation of the Federation International de Gymnastic (O2SN competition report of Official Persani of Central Java Province, 2010).

During the 2012 Gymnastic Regional Competition (Gymnastic Kejurda), the researcher interviewed all the participants' coaches on the availability of the mushroom gymnastic instruments in their respective regions. It was found that out of 25 participating regions, only 2 had mushroom gymnastic instruments. Not all the instruments followed the standard model as some of the instruments were modified mushroom gymnastic instrument produced by PB Persani. It was also found that the coaches were not aware of this condition and had never attempted to make their own modified mushroom gymnastic equipment. The athletes who joined the O2SN and POPDA were under 12 years old (the required minimum age to use the mushroom gymnastic instrument). The coaches urge the athletes to exercise on the mushroom gymnastic instruments where available or if they do not have it in their region, the athletes can practice using the instruments in the competition area one day prior to the competition (Soenyoto, 2012).

This study attempts to provide solution to this problem, i.e. developing an affordable mushroom gymnastic model which can be used by gymnastic coaches, gymnastic organizations, sport clubs, and elementary schools incorporating artistic gymnastic in Central Java.

The need for sports facilities will motivate gymnastic coaches and organizations to use the modified mushroom gymnastic model. The instrument produced is expected to enrich the artistics gymnastic facilities for beginner, junior and senior athletes.

\section{METHOD}

This study employs research and development method. Its main purpose is to produce an effective working product. The product was reviewed. Its trials were conducted until it reached satisfactory (Sugiyono, 2008, p. 407).This research uses qualitative research and model development. The data gathered are data from the initial step to trial.

The purpose of this study is to design and develop a mushroom gymnastic instruments which follows the assessment criteria set by the Deputy of Sport Achievement, The Assistant Deputy of Sport Science Application, and the Ministry of Youth and Sport in 2010 and 2011.

The data analysis procedures are conducted through the following steps: (1) gathering all of the observation data which include field observation notes, interview notes, and discussion notes. (2) conducting initial analysis and putting the data into categories. The categories are based on the product improvement, its effectiveness and whether the product meets its objective. (3) finding out the way the product could be improved and mapping the product effectiveness and whether the objective of the product is met. (4) Synthesising the process. This is conducted to process the overall data in order to achieve final product formation. (5) concluding the analysis.

To ensure the validity of the data, the researcher conducts data checking through several steps:

(1) observing the preferred starting, i.e. from initial product testing to the final testing; 
(2) triangulating... and investigating...;

(3) peer examination through discussion;

(4) discussion with guidance lecturer, experts, faculty observers, and gymnastic supporters;

(5) discussion with users. This final step is conducted after all the previous steps are completed. This is conducted to check the final result (Sugiyono, 2008, p. 309).

\section{RESULTS AND DISCUSSION}

Discussions that were conducted with personnels of Persani from Pati and Semarang regions. They include three gymnastic experts, three gymnastic instrument experts, ten supporting gymnastic experts, one faculty observer (a senior lecturer in gymnastic) and 36 mens' artistic gymnastic athletes that were subjected to the trial test. To ensure the quality of the instrument, product trial was conducted by deploying observation technique, conducting interview, documenting, and discussions.

The following table depicts the effectiveness of the mushroom gymnastic instrument:

Table 1. The criteria of effectiveness to be applied in the field research

\begin{tabular}{|c|c|c|c|c|c|c|c|c|}
\hline \multirow[t]{2}{*}{ No } & \multirow{2}{*}{$\begin{array}{l}\text { Observed Mushroom } \\
\text { Product }\end{array}$} & \multicolumn{7}{|c|}{ Tahapan Uji Coba Pemakaian } \\
\hline & & $\begin{array}{c}\text { Initial } \\
\text { Draft }\end{array}$ & Revision & $\begin{array}{l}\text { First } \\
\text { Trial }\end{array}$ & Revision & $\begin{array}{c}\text { Second } \\
\text { Trial }\end{array}$ & Revision & $\begin{array}{c}\text { Implement } \\
\text { ation }\end{array}$ \\
\hline 1 & Product Specification & $\mathrm{V}$ & $\mathrm{V}$ & $\mathrm{V}$ & - & $\mathrm{V}$ & - & - \\
\hline 2 & Safety Aspect & $\mathrm{v}$ & $\mathrm{V}$ & $\mathrm{V}$ & - & $\mathrm{v}$ & - & - \\
\hline 3 & Comfortable Aspect & $\mathrm{v}$ & $\mathrm{V}$ & $\mathrm{V}$ & - & $\mathrm{v}$ & - & - \\
\hline 4 & Product Effectiveness & - & - & $\mathrm{V}$ & - & $\mathrm{v}$ & - & $\mathrm{V}$ \\
\hline 5 & Product Achiement & - & - & $\mathrm{V}$ & - & $\mathrm{v}$ & - & $\mathrm{V}$ \\
\hline
\end{tabular}

The steps of implementation used to develop and assess the product's effectiveness is as follows:

Table 2. The steps for product implementation

\begin{tabular}{cccccc}
\hline No & Activities & \multicolumn{3}{c}{ Implementation Step } & \multirow{2}{*}{ Evaluator Team } \\
\cline { 3 - 5 } & & Process Procedure & Product & \\
\hline 1 & $\begin{array}{l}\text { The result of } \\
\text { development } \\
\text { presentation }\end{array}$ & $\mathrm{V}$ & $\mathrm{V}$ & $\mathrm{V}$ & $\begin{array}{l}\text { Gymnastics experts, Gymnastics } \\
\text { Instrument Experts, Supporting }\end{array}$ \\
& & & & $\begin{array}{l}\text { Gymnastics Experts, and Faculty } \\
\text { Observer }\end{array}$ \\
\hline 2 & $\begin{array}{l}\text { The } \\
\text { achiement of } \\
\text { final product }\end{array}$ & & $\mathrm{V}$ & $\mathrm{V}$ & $\begin{array}{l}\text { Gymnastics experts, Gymnastics } \\
\text { Instrument Experts, Supporting } \\
\end{array}$ \\
& & & & $\begin{array}{l}\text { Gymnastics Experts, and Faculty } \\
\text { Observer }\end{array}$ \\
\hline
\end{tabular}

The development of the mushroom gymnastic product is based on need analysis and follow the specification of an existing product, i.e. the Jansen Fritsen Mushroom Gymnastic.

After determining the criteria of the developed product, the next step was to develop the product. This was conducted through the following steps: (1) setting the 
objective and characteristics of the product, (2) identifying the characteristic of users, (3) applying the specification to the product, and (4) applying the objective to the product.

After designing the product, the product's initial prototype was made. This following picture is the mushroom gymnastic instrument prior to the expert's assessment and review:

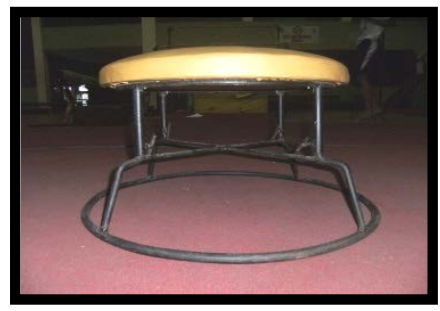

Picture 1. The mushroom gymnastics instrument (initial prototype)

Three gymnastic experts and three gymnastic instrument experts were asked to assess and review the initial prototype. The experts used an assessment criteria given by the researcher. A revised version was produced based on their recommendation. After passing the model development process through steps which are the modification of the Borg and Gall's, this research produces a mushroom gymnastic instrument product, named “Ts_UNJ 2013”. The comparison picture before and after revision were shown below:

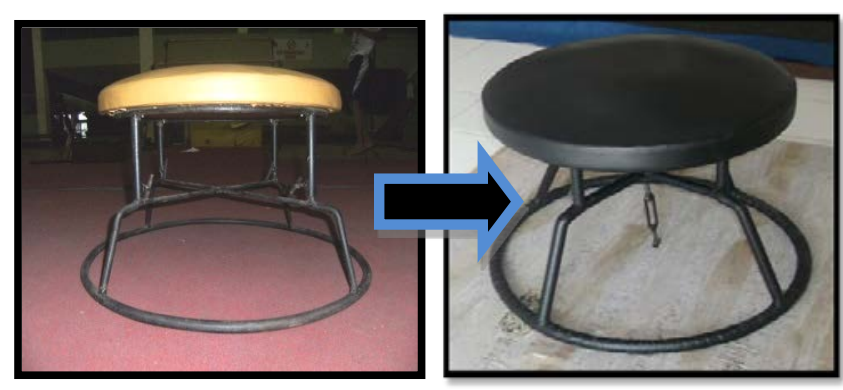

Picture 2. The initial prototype and the revised version or Ts_UNJ 2013

A comparison table were drawn to assess the developed model (Ts_UNJ 2013) and a Janssen Fritsen model which is available in the market. It compared the two products on several levels:

(1) The originality aspect.

The developed model is an original work by the researcher that was produced with distinguish features compared to other products available in the market. The aim of the production is to produce an instrument to improve the quality and achievement of the men's artistic gymnastic in Central Java.

(2) Exceptional innovation aspect.

The developed model has value in terms of its quality, the material used for assembling, the treatment of the product, and its maintenance. The model used only local material, i.e. iron, foam, paint, and leather. The product can be treated 
and maintained the same way as the Janssen Fritsen's product. However, this model is different to the Janssen Fritsen model as its height is adjustable to suit the athlete's height. By this way, beginner, junior and senior athletes can all use the instrument.

(3) Economic aspect.

The production cost is low, affordable and consequently efficient in the lens ofthe national sports management's perspective. A Janssen Fritsen product (including the delivery cost) is worth Rp. 14,000,000,- while to produce the developed model costs Rp. 3,000,000,- including the cost of delivery. Moreover, the production supports the local industry.

(4) Safety and comfort aspect.

The developed model has good safety standard as well a good comfort grade for beginner, junior and senior level athletes. This can be evaluated from the elasticity of the mushroom head, as well as the usage of ATI foam on its framework to avoid harming athletes.

(5) Subsidiary data completeness aspect.The developed model is equipped with manual book and CD as well as information on the trial result. This will make the user easy to learn and use the instrument.

There are several expectations from the development this instrument:

(1) In order to gain maximum result of this instrument, trainers should accompany, pay attention and help athletes in using the instrument.

(2) The instrument offers an alternative modified product from those existing in the market, particularly the current standard imported instrument (the Janssen Fritsen model). The developed product is more appropriate as it is modified to the need of the sporting branches.

However, there are limitations in developing this instrument. They are:

(1) the product was developed using limited technology;

(2) Borg and Gall's standard step was not used in consideration of finances and time limitation.

\section{CONCLUSION}

It can be concluded that the developed mushroom gymnastic instrument model product for the men's artistic gymnastic sports branch can be used (1) to improve the movement skill on the paddle horse for the junior and senior gymnastic athlete; (2) as a training instrument for men's artistic gymnastic in beginner, junior and senior level; (3) as the contest means for men's artistic gymnastics, specifically for beginners.

\section{REFERENCES}

Hoffman, D. and Hardy, F. (2011). Age Group Developmen Program for Mens Artistic Gymnastics. Switzerland: Federation Internationale De Gymnastique. 
Janssen-Fritzen Gymnastics s b.v. (2010). Top Instrument for Top Gymnasts. Ab Helmond: Netherlands.

JF Sport. (2010). Distributor Price List JF. Bekasi: Jatiasih.

Mahendra, A. (2001). Pembelajaran Senam di Sekolah Dasar. Jakarta: Departemen Pendidikan Nasional, 2001.

Patton, M. Q. (2009). Qualitative Research and Evaluation Methods [Metode Evaluasi Kualitatif]. Yogyakarta: Pustaka Pelajar.

PB Persani (2003). Struktur Akreditasi dan Pendidikan Wasit Senam Artistik Putra Program Nasional. Jakarta: PB Persani.

Saleh, S. (2004). Statistik Deskriptif. Yogyakarta: AMP YKPN.

Santoso, G. (2005). Metodologi Penelitian Fundamental. Jakarta: Prestasi Pustaka Publisher.

Setyosari, P. (2012). Metode Penelitian Pendidikan dan Pengembangan. Jakarta: Kencana.

Soenyoto, T. (2004). Pembinaan Olahraga Senam Artistik di Klub Senam Wimilia Kota Semarang. Semarang: Unnes.

Sugiyono (2007). Memahami Penelitian Kualitatif. Bandung: Alfabeta.

Sugiyono (2008). Metode Penelitian Pendidikan, Pendekatan Kuantitatif, Kualitatif dan R\&D. Bandung: Alfabeta. 